\title{
Ewa SŁAWKOWA
}

Katowice

\section{DYSKURSYWNIE O DYSKURSIE}

Swoista kariera słowa dyskurs i jego derywatów (dyskursywny, dyskursywność) w języku współczesnej humanistyki, a tym samym już nie tylko jego przydatność, ile wręcz niezbędność w opisach zagadnień dotyczących stanu kultury, w diagnozach zjawisk społecznych, czy analizach problemów współczesnej komunikacji, ze szczególnym uwzględnieniem literatury, a przede wszystkim zaś języka powoduje, iż konieczne staje się dokładniejsze przyjrzenie się zakresowi znaczeniowemu tego pojęcia, połączone $\mathrm{z}$ próbą prześledzenia etapów ewolucji znaczeniowej tego terminu w historii polszczyzny i jej odmianach. Pojęcie to bowiem, podobnie jak kilka podstawowych dziś terminów refleksji naukowej takich, jak: kultura, jezyk, komunikacja należy, jak już zauważono, do nieostrych i treściowo niedookreślonych (Gajda 1999).

Określenie dyskurs jako termin niezwykle poręczny, oddający tę szczególną cechę współczesnego świata, jaką jest jego wymiar komunikacyjno-interakcyjny, stało się jednym $\mathrm{z}$ najbardziej rozpowszechnionych, jednym $\mathrm{z}$ najczęściej używanych pojęć, którym $\mathrm{z}$ równym powodzeniem posługują się zarówno językoznawcy, jak i teoretycy literatury, badacze komunikacji, medioznawcy, antropolodzy, pedagodzy, a przede wszystkim socjologowie. Pojęcie to pojawia się równie często zarówno w tytułach prac z zakresu lingwistyki (B. Boniecka, Tekst potoczny a dyskurs, A. Duszak, Tekst, dyskurs, komunikacja międzykulturowa, J. Bujak-Lechowicz, Pojęcie szczęścia $w$ dyskursie naukowym i potocznym w ujęciu kognitywnym), jak i w tytułach rozpraw $z$ innych dyscyplin humanistycznych. Równie dobrze pisze się o dyskursie literackim, kobiecym, jak i o dyskursie władzy i dyskursie edykacyjnym (J. Ożdżyński, Wartościowanie $w$ dyskursie edukacyjnym). O słowie dyskurs nie wystarczy dziś powiedzieć, iż jest ono słowem-kluczem współczesnej kultury, ale równocześnie trzeba dodać, że stało się nazwą osobnej dyscypliny badawczej - analizy dyskursu (van Dijk 2001).

Przekonanie o tym, iż dyskursywny charakter ma nasza rzeczywistość, jak i o tym, że żyjemy w świecie zmieniających się nieustannie dyskursów, należy do 
kanonicznych twierdzeń, po wielokroć wygłaszanych i artykułowanych w pracach i rozprawach $\mathrm{z}$ różnych dziedzin nauki.

Jednak to ani rzeczywistość ponowoczesnej, postindustrialnej i medialnej kultury, ani też problem dziedzictwa nowoczesności, wobec których tak chętnie stosuje się interesujący nas tu termin - przypomnijmy w tym miejscu tytuł słynnej książki Jurgena Habermasa Filozoficzny dyskurs nowoczesności (2005) - staną się przedmiotem naszych rozważań i też nie fenomen obecności dyskursu w różnych obszarach nauki będzie przyciągał naszą uwagę. Punkt widzenia, który przyjmujemy w tym szkicu, jest inny. W polu naszego zainteresowania znajdzie się wyłącznie historia i semantyka tego pojęcia w języku polskim.

O tym, że w wypadku leksemu dyskurs mamy do czynienia z różnymi znaczeniami tego terminu, przekonuje lektura artykułów $\mathrm{z}$ różnych gałęzi nauki oraz dokładniejsza analiza kontekstów językowych, w których on się pojawia. Wyraz ten jest używany $w$ różnych znaczeniach, jednak nigdy nie są to znaczenia sprzeczne ani nawzajem się wykluczające. Pozostając w zgodzie z opinią Gajdy, który w odniesieniu do tego leksemu mówi o „rodzinie znaczeń starych i nowych” (Gajda 1999) powiemy, iż wobec zagadnienia nieostrości znaczeniowej tego wyrazu, możemy z powodzeniem odwołać się do instrumentarium semantyki kognitywnej i proponowanego przez nią modelu sieciowego znaczenia wyrazów. W takim ujęciu na znaczenie słowa składają się zarówno sensy zlokalizowane w centrum tego modelu (są to tzw. znaczenia prototypowe), jak i czasem liczne znaczenia, oddalone od podstawowego jądra znaczeniowego, umieszczone na peryferiach modelu (Nowakowska-Kempna 1993).

Znaczenie prototypowe leksemu to znaczenie najbardziej rozpowszechnione w świadomości użytkowników języka, najlepiej w niej utrwalone, co potwierdza praktyka leksykograficzna. W wypadku dyskursu to właśnie znaczenie ma najlepszą i najdłuższą dokumentację słownikową.

Jeżeli sięgniemy po definicję tego leksemu do historycznych i współczesnych słowników języka polskiego, to dość szybko stwierdzimy, że jest on w tym znaczeniu, które określamy tu mianem prototypowego, dobrze zakorzeniony w tradycji polszczyzny. Zauważymy, iż przeszedł on znamienną ewolucję: od słowa będącego w częstym użyciu w języku doby średniopolskiej i w początkach nowopolskiej, w którym obsługiwał głównie sferę polityki i życia publicznego, poprzez etap funkcjonowania w języku ogólnym w znaczeniu bardziej neutralnym, z biegiem czasu stał się wyrazem mało używanym, w słownikach współczesnej polszczyzny opatrzonym wyłącznie kwalifikatorem „dawny czy książkowy”. W Uniwersalnym stowniku języka polskiego czytamy: „dyskurs, tac. discursus, książk. a) dyskusja, w której poważny temat omawiany jest w sposób uporządko- 
wany i logiczny; b) wywód, np. w rozprawie filozoficznej lub w dziele literackim, przeprowadzony na zasadzie ściśle logicznego wnioskowania" (Dubisz 2003, 747). Kompetencja językowa podpowiada nam jeszcze, co nie znajduje odzwierciedlenia we współczesnych słownikach języka polskiego, iż wyraz ten bywa też używany jako snobistyczny odpowiednik każdej dyskusji czy rozmowy.

Mając w polszczyźnie utrwalone długą tradycją znaczenie, wyraz dyskurs niespodziewanie przeżywa dziś swoisty renesans jako termin naukowy, niezwykle przydatny, choć z całą pewnością nadużywany.

Dyskurs jest funkcjonującą już w spolszczonej formie w XVI-wiecznej polszczyźnie pożyczką z łaciny (łac. discursus - mowa, rozmowa, dyskusja, przemówienie; discurere - biec w różne strony), $\mathrm{z}$ której przeszedł zapewne wraz z polityczno-kaznodziejskim słownictwem przejętym $\mathrm{z}$ tradycji retorycznej. M. Korolko w swojej Sztuce retoryki. Przewodniku encyklopedycznym pisze o dyskursie retorycznym i jego funkcjach uwarunkowanych „, wiedzą z zakresu teorii poznania, etyki, psychologii itp." (Korolko 1990, 45). Zauważmy, iż abstrakcyjne znaczenie 'dyskursu' jako mowy, przemówienia, dyskusji pochodzi od czasownika oznaczającego konkretną czynność. Mamy tu zatem do czynienia z przykładem klasycznego procesu kształtowania się znaczenia wyrazu, przebiegającym najczęściej od znaczenia konkretnego (tu: związanego z ruchem fizycznym) do bardziej abstrakcyjnego (tu: znaczeń związanych z mówieniem i jego interakcyjnym wymiarem).

Słownik polszczyzny XVI wieku $(1972,295)$ zawiera bogatą dokumentację użyć tego wyrazu oraz notuje dwa jego znaczenia: 1. Dyskusja, dysputa, wymiana $z$ dań [discursus - przechodzenie, latanie tam i sam - przebieganie]; 2. Wywód, wypowiedź, dowodzenie. Już zatem na początku doby średniopolskiej 'dyskurs' jest synonimem dysputy i rozmowy; dowodzenia i wywodu, a więc ma to znaczenie, które leksem ten - jakkolwiek rzadko dziś używany - utrzymał do dziś.

Do utrwalenia tego wyrazu w języku polskim przyczynił się z całą pewnością wiek XVIII, znajdujący się pod przemożnym wpływem oświeceniowej kultury francuskiej z jej głośną Discours de la méthode Kartezjusza. Słowo 'dyskurs' pojawiało się w tym czasie w tytułach innych, mniej znanych polskiemu czytelnikowi dzieł francuskiego oświecenia, na przykład w rozprawie na temat języka Antoine'a Rivarola Discours sur l'universalité de la langue française (1784). W Stowniku języka polskiego S.B. Lindego (t. 1, 580) obok hasła 'dyskurs' - rozmowa, a także 'dyskursik', odnajdujemy hasło 'dyszkurować' - rozprawiać. Słownik języka Adama Mickiewicza (t. 2, 290) odnotowuje 'dyskurs' jako rozmowę, rozprawianie o czymś, ilustrując przykładem z Pana Tadeusza: „Wtem Stolnik [...] wszczął dyskurs; zaczynali z niemcem dyskurs nazbyt żwawy”.

Jeśli nasze współczesne myślenie o dyskursie kształtuje dziś przede wszystkim tradycja badań anglosaskich, to kluczowe ich pojęcie - discourse analysis - jest przecież francusko-łacińskiej proweniencji. 
$\mathrm{Z}$ czasem z pojęciem dyskurs zaczyna się łączyć już nie tylko wywiedzioną $z$ tradycji retorycznej mowę, czy przemówienie, ale zaczyna ono oznaczać przede wszystkim szczególny rodzaj rozmowy, czy dyskusji. Coraz większego znaczenia nabiera takie myślenie o dyskursie, które łączy go z każdym przekazem komunikacyjnym, z każdym tekstem polegającym na negocjowaniu znaczeń między interlokutorami (indywiduami, ośrodkami). Pojęcie to jest w końcu identyfikowane z każdym aktem komunikowania, niezależnie od medium, za pomocą którego ten akt się dokonuje. Może więc dotyczyć znaczeń „komunikowanych” także przez przedmioty materialne, organizacje przestrzeni społecznej etc. („http://pl.wikipedia.org/wiki/Dyskurs"). Termin ten utożsamiany bywa wreszcie z procesem przebiegającym w kontekście określonej praktyki życia społecznego, aż staje się nazwą osobnej dziedziny badawczej.

Jak widzimy, spektrum znaczeniowe dyskursu jest rozległe; obejmuje zarówno znaczenia wywodzące się z tradycji retorycznej, związane z zagadnieniami komunikacji, jak i sensy ukształtowane w obszarze przestrzeni społecznej.

\section{$* * *$}

Gwałtownemu rozwojowi lingwistyki w XX wieku, zarówno tej systemowej, zajmującej się odkrywaniem reguł budowy i działania systemu językowego, jak i przede wszystkim poststrukturalistycznej, skupiającej się na zagadnieniach parole zawdzięczamy pojawienie się całej wiązki nowych znaczeń słowa 'dyskurs'. Tym razem są to znaczenia stricte naukowe. To na gruncie językoznawstwa, w obszarze takich jego nurtów, jak rodzące się w latach 1965-1975 gramatyka i lingwistyka tekstu oraz lingwistyka mowy, rodzi się, kształtuje i utrwala nowe znaczenie interesującego nas tu pojęcia.

$\mathrm{Za}$ jego twórcę należy uznać francuskiego lingwistę Emila Benveniste'a (1966), którego koncepcja odróżnienia dwóch poziomów wypowiadania: histoire i discours legła u podstaw myślenia o dyskursie w odmiennych niż dotychczas kategoriach i okazała się prekursorska wobec wszystkich powstających w następnych latach prac i teorii na ten temat. W tym ujęciu 'plan dyskursu' przedstawiany jest jako bezpośrednio związany z sytuacją mówienia, w której nadawca 'tu i teraz' (hic et nunc) kieruje swoją wypowiedź do odbiorcy. Sytuację tę wyznaczają czas teraźniejszy, zaimek osobowy ja oraz zaimki wskazujące. Ta charakterystyka nie dotyczy „planu historii”, który przedstawiany jest jako niezwiązany z sytuacją wypowiadania.

Myślenie w tych dualistycznych kategoriach legło u podstaw francuskiej narratologii, stając się punktem odniesienia dla prac Tzvetana Todorova, Claude'a Brémonda, A. Greimasa i proponowanych przez tych badaczy strukturalnogeneratywnych modeli opowiadania. „Historia”, czyli to, o czym się opowiada 
(postacie, zdarzenia), zawiera „sens” i znaczenie opowiadania (fabuła, materiał narracyjny), traktowana jest tu zawsze jako nadrzędna wobec „dyskursu”. Natomiast „dyskurs” rozumie się jako sposób jej przedstawiania, czyli to, jak się opowiada (parametry czasu, stosunek narratora do historii, ukształtowanie narracji, wypowiedzi bohaterów).

Od czasu teorii Benveniste'a i Jakobsona pojęcie dyskurs zdobywa sobie stałe miejsce $\mathrm{w}$ badaniach tych wszystkich szkół współczesnego językoznawstwa (francuskiego, anglosaskiego, a także polskiego), które koncentrują się na badaniu komunikacyjnych wymiarów wypowiedzi w ich społecznym i pragmatycznym uwikłaniu. Poprzez 'dyskurs', najogólniej rzecz ujmując, rozumie się odtąd w lingwistyce całokształt działań komunikacyjnych podporządkowanych określonej funkcji.

Jeśli w ujęciu amerykańskiego lingwisty Z.S. Harrisa (1969) jest on jeszcze utożsamiany z prostą sekwencją zdań, którą badacz - jako dystrybucjonista - postrzega jako miejsce ich szczególnego rozmieszczenia (dystrybucji), to w wielu następnych koncepcjach z przełomu lat 80 . i 90. pojęcie to nabiera zdecydowanie dynamicznego charakteru. Zaczyna oznaczać proces, zdarzenie komunikacyjne, całokształt działań mownych, łączących nadawcę z odbiorcą. W różnych pracach z tego czasu kładzie się nacisk na interakcyjny, dialogowy charakter tej całości komunikacyjnej, którą określa się mianem dyskursu. Podkreśla się, co szczególnie ważne dla ujęć - jego wymiar pragmatyczny, usytuowanie w czasie i przestrzeni.

\section{$* * *$}

W badaniach nad dyskursem coraz większego znaczenia zaczyna nabierać szeroko rozumiany kontekst społeczny, w jakim owa całość komunikacyjna powstaje i ma funkcjonować. Za dyskurs coraz częściej uważa się określony typ użycia języka warunkowany praktyką społeczną, czy wręcz zdeterminowany panującą ideologią (dyskurs polityczny, naukowy, medialny, administracyjny). Termin dyskurs to współcześnie sposób rozumienia języka jako działania jego użytkowników, jako jednostka komunikacyjna języka, czy pewien ciąg spójnych i relewantnych zachowań komunikacyjnych funkcjonujących w określonej sytuacji w danym kontekście, których postać, opierająca się na obowiązujących wzorcach społecznych i kulturowych, zależy od tego, kto mówi, do kogo, w jakim celu i w jakiej sytuacji.

Podczas gdy w tradycji badań francuskich (Maingueneau 1996) wyraźnie akcentuje się opozycję między dyskursem a tekstem, a tym samym między analizą dyskursu a lingwistyką tekstu, to w pracach anglosaskich fenomeny te bywają często utożsamiane (Duszak 1998). Badacze francuscy dynamicznemu, ukontek- 
stowionemu dyskursowi przeciwstawiają względnie niezależny od kontekstu, zamknięty i ukształtowany składniowo tekst.

$* * *$

Interesujący etap w rozwoju badań nad dyskursem rozpoczyna się w momencie, kiedy uzyskują one perspektywę interdyscyplinarną, tzn., kiedy pojawiają się w nich wątki poszukujące związków między jego strukturą językową, a społecznym doświadczeniem tworzących go użytkowników. „Analiza dyskursu politycznego jest poprawna i empirycznie istotna tylko wtedy, gdy udaje jej się połączyć właściwości struktur dyskursywnych z właściwościami procesów politycznych” - stwierdza T. A. van Dijk („http://pl.wikipedia.org/wiki/ Dyskurs”).

Pod pojęciem dyskursu rozumie się także „system zasad, które regulują tworzenie zbioru wypowiedzi charakterystycznych dla danej formacji społecznej lub ideologicznej, np. dyskurs feministyczny, religijny, administracyjny” (Miczka 2002, 41-42).

Szczególną rolę odegrały badania nad dyskursem historycznym, w których ukazano jego uwikłanie w istniejący porządek polityczny oraz stwierdzono, że historia to dyskurs władzy (Foucault 1998).

Historia leksemu dyskurs w języku polskim obejmuje zatem dwa zasadnicze etapy: pierwszy $z$ nich - kiedy rodzi się i ugruntowuje jego znaczenie prototypowe jako 'mowy', 'przemowy', 'dyskusji', 'logicznego wywodu' oraz drugi - kiedy zaczyna on funkcjonować także, a z czasem głównie jako termin naukowy (dyskurs nauk ścisłych, humanistycznych, dyskurs autobiograficzny, ideologiczny, społeczny), wchodząc coraz częściej w obieg takiej odmiany funkcjonalnej polszczyzny ogólnej, jaką jest styl publicystyczno-medialny.

\section{Bibliografia}

Baker M., K. Malmkjaer K. (red.), 1996, Routledge Dictionary of Language and Linguistics, London - New York.

Bartmiński J., Boniecka B. (red.), 1998, Tekst. Problemy teoretyczne, Lublin.

Boniecka B., 1998, Tekst potoczny a dyskurs, [w:] Bartmiński J., Boniecka B. (red.), Tekst. Problemy teoretyczne, Lublin.

Benveniste E., 1966, Les niveaux de l'analyse linguistique, [w:] Problèmes de linguistique générale, T.1, Paris.

Bujak-Lechowicz J., Pojęcie szczęścia $w$ dyskursie naukowym i potocznym w ujęciu kognitywnym, Piotrków Trybunalski 2006.

Dijk van T.A. (red.), 2001, Dyskurs jako struktura i proces. Przeł. G Grochowski, Warszawa.

Dobrzyńska T., 1993, Tekst próba syntezy, Warszawa. 
Dubik A. (red.), 2002, Poznanie - podmiot - dyskurs, Idee i dziedzictwo frankofońskiej tradycji epistemologicznej, Torun.

Dubisz S. (red.), 2003, Uniwersalny stownik języka polskiego, Warszawa.

Duszak A., 1998, Tekst, dyskurs, komunikacja międzykulturowa, Warszawa.

Foucault M., 1998, Trzeba bronić społeczeństwa. Wykłady w College de France 1976, Warszawa.

Gajda S., 1999, Wspótczesny polski dyskurs naukowy, [w:] S. Gajda (red.), Dyskurs naukowy - tradycja i zmiana, Opole.

Grzegorczykowa R., 1998, Gtos w dyskusji o pojęciu tekstu i dyskursu, [w:] Bartmiński J., Boniecka B. (red.), Tekst. Problemy teoretyczne, Lublin, s. 37-43.

Habermas J., 2005, Filozoficzny dyskurs nowoczesności, Kraków.

http://pl.wikipedia.org/wiki/Dyskurs

Korolko M., 1990, Sztuka retoryki. Zarys encyklopedyczny. Warszawa.

Labocha J., 1996, Tekst, wypowiedź, dyskurs, [w:] S. Gajda, M. Balowski (red.), Styl a tekst, Opole, s. 49-53.

Linde S.B., 1951, Stownik języka polskiego, Warszawa.

Maingueneau D., 1996, Les termes clés de l'analyse du discours, Paris.

Mayenowa M. R.(red.), 1972, Stownik polszczyzny XVI wieku, Wrocław.

Miczka E., 2002, Kognitywne struktury sytuacyjne i informacyjne $w$ interpretacji dyskursu, Katowice.

Nowakowska-Kempna I., 1993, Definiowanie znaczeń w kognitywizmie, Wybrane zagadnienia, [w:] Bartmiński J., Tokarski R. (red.), O definicjach $i$ definiowaniu, Lublin.

Ożdżyński J., 1999, Wartościowanie w dyskursie edukacyjnym, Kraków.

Szymczak M. (red.), 1978, Stownik jezyka polskiego, Warszawa.

Urbańczyk S. (red.), 1964, Stownik języka Adama Mickiewicza, Wrocław-WarszawaKatowice.

\title{
DISCOURSIVELY UPON THE DISCOURSE
}

\author{
Sum mary
}

The article presents a lexical and semantic study of the discourse, one of the most widespread terms of modern human sciences. We begin with etymology, and then demonstrate various stages of the development of the meaning of the term in the history of Polish. The lexem "discourse", well established in the linguistic tradition of Polish, has undergone a characteristic evolution: first, a borrowing from Latin (discurere - "go in diverse directions"), it then became popular in the $16^{\text {th }}$ through $18^{\text {th }}$ centuries as a rhetorically marked Polish (particularly with the view of political speeches and sermons) to signal a kind of discussion and logical exposition of argumentation. Recent contemporary Polish gives this term a slightly archaic and bookish sense. 
At the same time, however, "discourse" has become a strictly scientific, scholarly term which carved for itself a special discipline of research (discourse studies). In the 1960s and 1970s the work of such linguists as Emile Benveniste or Roman Jakobsen helped to shape the meaning of discourse as a process of speaking, an interactive and dialogic communicative behaviour which sees language as conditioned by diverse social practices and/or ideologies (e.g. historical, scholarly, or feminist discourse). 